\title{
Communications and Industrial Mission
}

\author{
by Max Stetter
}

My involvement in pastoral work in a new industrial parish on the outskirts of Thika had very little to do with the communication skills I had acquired in a number of courses over the years. In the workers' housing estates where there is no electricity, the electronic era is delayed.

The pastoral ministry among the workers has taught me more about communications than courses in radio and television production. The world of industrial labour was so new to me that $I$ was all eyes and ears during the time I had visited the major factories and hundreds of workers' homes. I was struck by the contrast between a flourishing industry on one side of the road and an impoverished proletariat on the other side.

I was intrigued by the observation that as many as four workers could share a small room without electricity, which serves as dormitory, sitting room and kitchen at the same time. Little wonder that the majority of workers cannot afford to have their families with them. I met a new nomadic tribe, uprooted from their home traditions, exposed to exploitation in their places of work and residence, people who live in constant fear of being declared "redundant".

The majority of workers in St. Mulumba parish are employed as casuals in a multinational pineapple-growing and processing corporation. As farm "hands" they gain very little insight into an operation that features bulldozers, irrigation schemes, assembly lines, comprehensive transport and marketing systems - all in all an outfit of about 10.000 labourers and as much as 80.000 hectares of land. A plantation worker ist too much preoccupied with the problem of how to survive during the off-season as to be worried about the effects on his health and the land of fertilizers, pesticides and polythene that is ploughed back in return of a rich yield.

Economist Richard Barnet pictures the multinational corporation as a giant. The brain lives in the skyscrapers in New York, London, Frankfurt and Tokyo. Blood is capital pumped through the system by a global network of banks. The world's financial centres are the heart, while the hands reach out into the Third World for cheap labour to make goods for sale in industrial countries.

Before the arrival of the giant, the Kenya Government had launched a small-holders' scheme in Thika through which farmers were encouraged to plant pineapples on their land and sell them to the Company. The monster succeeded in pressurizing the government into selling out the scheme, getting a most favourable lease of land and monopoly rights on top of it all.

As a result of this process, the land was turned into gold mines and the farmers into a landless, dependant working class. The records of the history of this agri-business

Max Stetter ist Pfarrer in der Katholischen Pfarrei St. Matia Mulumba in den Außenbezirken von Thika in Kenia und befaßt sich seit Jahren mit der Kommunikationsproblematik. 
from its inception in 1916 and its operations in Hawaii, Mexico, Guatemala, Costa Rica, South Africa, the Philippines and many other countries in the world gave me an insight into the works of mass media corporations which undertake standardizing, packaging and marketing not of bananas and pineapples but of information. I had shared the frustration of a "hand" in the information trade with no influence on the marketing system as such. I became aware that it makes little difference whether a hand and body lotion, a political "philosophy" or the Kingdom of God is marketed by the network - the consistency in each case is the same, namely minced meat and the taste is that of hamburger ( $\mathrm{Big} \mathrm{Mac}$ ). The microprocessing is taken care of by some little miraculous chips from Silicon Valley.

This is the case where the handy old communication model of sender-receiver-message has been rendered obsolete. My dream of having found the magic formula of communication by choosing the most effective channel for the Good Message and broadcasting it to the widest audience, had ended in a rude awakening. I decided that my contribution to communication should be that of the healing ministry among the casualties in the "global village".

When I had started organising workers' movements in the parish, I was confronted with all the symptoms of what Ngugi wa Thiong'o, the renowned Kenyan writer had termed the "culture of silence". The language of the victims was a vernacular of lethargy and resignation. "Tufanye nini?" — "What can we do?", "Tuvumilie" "Let's stick it out", "Shauri ya Mungu" - "It's all God's will." I could easily recognise the standard phraseology of religious communicators in the service of the system who are more inspired by the vested interests of the network than by the work of the Holy Spirit. "I have found it" - "I am saved" — "Christ is the answer". The chaplain of the University of Nairobi in one of his sharp sermons once countered: "And what is the question?" The caste of intermediaries and system integrators deal only in answers because they would not jeopardize their precious air time allocated by a generous government with unsettling questions.

The workers in St. Mulumba parish were simply afraid of relating their day to day experiences because a foreman, headman, supervisor or superintendent might overhear them and have them sacked. Media provoke a response and at the same time offer protection, so we started experimenting with photolanguage and codes about workers' problems with positive results. The most congenial code proved to be the role-play. The playful slipping into roles and working on them in a team effort released unexpected talents and provided a means for conscientization, protest and celebration. As from that time no occasion was missed by the workers for "displaying " their very own problems such as oppression, insecurity, bribery, lack of transport, poor public health services, housing problems, food shortages and police harassment. Drama became an essential part of every celebration be it a youth festival, Labour Day or the parish feast.

Once the workers had discovered their medium, they started to explore the potential of biblical plays as well as of African folk stories. Whatever the code, the message was topical and articulate. e. g. Parents with marriageable daughters tend to think that a young man who has found employment in town must be rich and they are not ashamed to ask for exorbitant payments in the course of marriage negotiations. - A group of young workers attacked these unfair practices by performing Jacob's story who was made to work for as much as fourteen years without payment to be allowed to take Rachel home as his wife. 
Another example: in a Young Christian Workers' meeting a "social enquiry" stated the plight of job seekers and after several personal experiences were related, it became clear that jobs are not allocated according to qualifications but on bribes. During the parish feast members of the $\mathrm{Y}$. C. W. staged the traditional story of the king who had lost his most precious ring and had promised a generous reward to whoever of his subjects who would find it. It so happened that the beggar was the lucky one. He folded the treasure in his handkerchief and hid it deep in his pockets. His happiness was not to last for long because the royal gatekeeper refused him entrance unless he was prepared to share his reward equally with him. Having crossed the royal court, he was stopped by the doorkeeper and told to return to where he came from unless he would part with the other half of the reward which the king was surely going to give him. Eventually he was ushered into the audience hall. The king was overjoyed to have his treasured ring back and promised him half of his kingdom. $\mathrm{He}$ did not trust his ears when he heard his humble subject in a low voice asking for a hundred strokes of the cane. Having heard of the shady deal of his courtiers the king meted out the "handsome" reward to his watchmen and sent the beggar home with a generous present for helping him uncover the crooks. "Every day is for the crook but one day is for the deceived". The reaction of the spectators of the play left no doubt that they had all along seen job seekers, factory gates, security guards and personnel managers.

My media training had left me with very little respect for the Gutenberg tradition but together with the workers I have learnt to appreciate the power of a local newsletter; it became a platform for young workers who were frustrated sending letters to editors who were afraid or simply did not bother to publish them. In the beginning HABARI ZETU (Our News) was a straight-forward Church publication with announcements, reflections on the liturgical seasons and parish news. Once the workers had realised that their contributions were welcome, it became a down-to-earth hot news forum. Cartoons were interpreted and discussed as group media in workers' meetings. I discovered that only cartoons from their own world were helpful media; what was outside this framework remained a puzzle such as the cartoon for the World Day of Communications.

Of late, every single issue of the monthly newsletter contains a personal experience from the shop floor which is being discussed as "social enquiry" during meetings. The contributions are increasing and we are about to start a cyclostyled workers' newspaper. Last year when more than 300 workers were dismissed by the fruit-processing company, in what was regarded by the workers a most unfair manner, the Kikuyu story of the monster that can devour entire villages proved the topical and political power of traditional African stories. The fact that the traditional as well as the multinational monster is living near a river, left very little to the phantasy of the readers.

Events no longer were interpreted as "circumstances beyond control" or even God's will - this was exemplified by three young ladies, members of the Y. C. W. who had organised a spontaneous collection and led a group of dismissed women by bus to the President's Office.

On Labour Day, 1981 after a Mass on the theme of the day, the groups performed workers' drama on the Church compound and their enthusiasm spilled over into an action that was unprecedented in the history of the celebration of this day. About 
sixty workers with banners, posters and spontaneous songs marched into a crowded station. Two speeches were delivered by members of the groups to a surprised audience of government and union officials and thousands of workers. It was communications at its best when workers articulated their grievances, no longer depending on self-styled intermediaries. This break-through was duly celebrated in a disco at the parish after initial fears of being imprisoned had proved baseless; the organisers of the day had simply been overtaken by events. Communication for the workers was no longer just a group event but had become a happening in a mass rally.

Another important development with regard to communication among the residents of the workers' housing estates was the establishment of Small Christian Communities (Basic C. C.). I had regarded this as the most difficult task among people from all tribes of the country. I discovered that tribalism is not inherited but created by people who have a vested interest in keeping workers isolated. The idea of Small Christian Communities immediately caught on among the leaders of the workers' movements and the greatest asset was their experience in action orientated Bible reflection and their experience in the psycho-social method of adult learning.

Every Sunday one of the communities is responsible for the liturgy; often they present their Gospel interpretation in the form of role plays in which they relate the Gospel message to their day-to-day experiences. The shared bidding prayers no longer were abstract and stereotyped invocations but expressions of their working life in the light of Christian hope. Delegates from the various communities began to communicate directly with municipal authorities, transport companies and public service offices. The results of a survey carried out by young workers with the help of a university lecturer, revealed serious health and hygiene problems in the housing estates. The municipal health inspector and the councillor of the area were invited for discussions. In a subsequent issue of the parish newsletter a member of one of the Christian communities concluded that landlords do not live near their tenants and preferably remain anonymous, officers of the local government keep away from places with poor road communication, lack of electricity and recreational facilities and therefore it is the residents themselves who have to suffer when disease strikes due to unhygienic conditions. He made an appeal to his fellow workers to join hands in an effort to uplift the living conditions.

Small Christian Communities can become platforms for power politics and they can turn into pious circles for escapists. Christian workers groups can assume the role of petty trade unions and they may become first aid stations for the casualties of industrial progress. What makes these groups "salt of the earth" is deep personal sharing of faith, the basis of all communication. In the beginning the priest will invariably be assigned the role of the professional communicator and the "expert" of the Word of God. If he falls into the trap he will reinforce the status quo of the hierarchical Church, if, however, he can be a listener, he will witness the dawn of a new dynamic Church.

For a long time I had seen the role of the communicator in terms of the well known communication model; I now believe that the communicators role is to create an atmosphere where each and everyone is encouraged to communicate himself/herself. Group media can have a liberating power in a situation of repressive mass media manipulation. It is time for the Church to reconsider her media policies. Is it justifyable to invest huge amounts of money into hardware for denominational studios and the training of a few specialists who work as casual and seasonal "hands" in the 
network to witness to the presence of the Church in oppressive systems of communication?

Third World theologians, especially in Latin America, have begun to practice the Church's "option for the poor"; they have left their comfortable studies in order to read the Gospel with the eyes of the poor. When will religious communicators leave their air-conditioned "control"-rooms and join grass-root communities, not to look for stories but to communicate?

\section{ZUSAMMENFASSUNG}

Die Pastoralarbeit in der neuen Industriepfarre Thika hat eigentlich wenig mit Kommunikationstechniken zu tun, wie der Verfasser sie in verschiedenen Kursen erlernt hat. Dennoch hat ihn diese pastorale Arbeit mehr über Kommunikation gelehrt als Kurse in Produktion für Hör- und Sehfunk. Die Welt der industriellen Arbeit war so neu für ihn, daß er Auge und Ohr war, als er zum ersten Mal die größeren Fabriken und Hunderte von Arbeiterwohnungen in seiner neuen Pfarrei besuchte. Der Gegensatz zwischen einer blühenden Industrie auf der einen und dem verarmten Proletariat auf der anderen Seite erschütterte ihn: bis zu vier Arbeiter teilten sich einen kleinen Raum ohne Strom, der als Schlaf-, Wohn- und Kochstätte gleichzeitig diente. Klar, daß sie keine Familien haben konnten. Sie waren ein neuer Nomadenstamm, entwurzelt und preisgegeben der Ausbeutung an ihrem Wohn- und Arbeitsplatz; sie leben mit der ständigen Furcht, für „überflüssig“ erklärt zu werden.

Die meisten Mitglieder der Sankt Mulumba Pfarrei sind als Gelegenheitsarbeiter in einem multinationalen Ananas-Betrieb mit 10.000 Arbeitern und 80.000 Hektar Land. Ein solcher Plantagenarbeiter ist viel zu beschäftigt mit der Frage seines Überlebens außerhalb der Saison, als daß er nach den Folgen der Arbeitsbedingungen für seine Gesundheit und nach den Folgen der Chemie für das Land fragen würde.

Vor der Ankunft der Multinationalen hatte die Kenianische Regierung ein Projekt für Kleinbauern zum Anbau von Ananas gefördert, das aber dann auf Druck des Großkonzerns aufgegeben wurde. Die Folge war, daß man zwar mehr Geld machte, die Bauern aber in eigentumslose Arbeiter verwandelt wurden ... Aus diesen und ähnlichen Entwicklungen multinationaler Unternehmungen in anderen Ländern wurde dem Verfasser die Wirkweise der Massenmedienkonzerne klar. Es macht dabei wenig Unterschied, ob sie dann Kosmetika, politische „Philosophien " oder das Reich Gottes vermarkten - die Empfänger sind in jedem Falle gleich machtlos. Hier versagt das alte handliche Kommunikationsmodell von Sender - Botschaft und Empfänger.

Als der Verfasser die Arbeiterbewegung in der Pfarrei begann, wurde er mit der „Kultur des

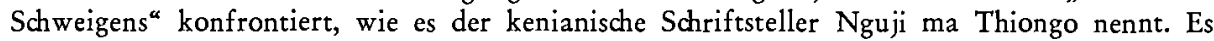
war die Sprache der Lethargie und der Resignation ... Aber Medien provozieren eine Antwort und bieten gleichzeitig Schutz. So begann man mit Versuchen in Fotosprache und mit einer Sammlung von Ausdrücken für die Probleme der Arbeiter. Der beste Ausdruck wurde zum Rollenspiel weiterentwickelt. Das spielerische Schlüpfen in bestimmte Rollen und das Spiel im Team förderten unerwartete Talente und boten Möglichkeiten einer neuen Bewußtseinsbildung, des Protestes und der Feier. Seitdem verpaßten die Arbeiter keine Gelegenheit mehr, ihre eigenen Probleme wie Unterdrückung, Unsicherheit, Bestechlichkeit, mangelnde Gesundheitsfürsorge, Wohnprobleme darzustellen. Das Spiel (Drama) wurde wesentlicher Teil jedes Festes und jeder Feier.

Nachdem die Arbeiter so „ihr" Kommunikationsmittel entdeckt hatten, widmeten sie sich auch biblischen Spielen und afrikanischen Volkserzählungen, die etwas zur eigenen Lage dieser 
Arbeiter aussagten ... Diese ${ }_{n}$ Spiele" ${ }^{\text {w }}$ wurden schnell von den Zuschauern verstanden und in die Wirklichkeit übertragen.

Seine Medienerfahrung brachte dem Verfasser außerdem wenig Respekt für die Gutenbergtradition. Aber zusammen mit den Arbeitern hat er die Wirkung eines lokalen Nachrichtenblattes schätzen gelernt. Es wurde Forum für die jungen Arbeiter, die es leid waren, Briefe an die Zeitung zu schreiben, die doch nicht veröffentlicht wurden. Mit ihrem eigenen Blatt "Habari Zetú“ (Unsere Nachricht) - ehemals ein einfaches Pfarrblatt - haben sie sich eine Plattform geschaffen, wo sie ihre eigene Wirklichkeit, etwa auch durch Karikaturen, kommentieren. Jede monatliche Ausgabe des "Newsletter" bringt persönliche bittere Erfahrungen, die als "Soziale Frage" in Versammlungen diskutiert werden. Dies führt dazu, daß die Ereignisse nicht mehr als gottgewollt angesehen werden, sondern daß sich so spontan Initiativen bilden und ein neues Selbstbewußtsein wächst. Das zeigte sich etwa am Labour Tag 1981 darin, daß zum ersten Mal nach der Messe und einem Rollenspiel bei der Kirche die Begeisterung so groß war, daß etwa sechzig Arbeiter mit Bannern in das an diesem Tage überfüllte öffentliche Stadion zogen und dort zwei Reden vor dem erstaunten Publikum und den Regierungsvertretern hielten, wo sie ihre Sorgen und ihren Unmut ausdrückten ...

Ein anderes wichtiges Kommunikationsmittel wurden die christlichen Basisgemeinschaften. Die Idee dafür packte die Führer der Arbeiter sofort; als größter Vorteil zeigte sich jetzt die Erfahrung der aktionsorientierten Bibelarbeit und der Erwachsenenbildung. An jedem Sonntag ist jetzt eine bestimmte Gruppe für die Gestaltung der Liturgie verantwortlich; oft wird dabei die Bibelinterpretation im Rollenspiel dargelegt. Die Fürbitten waren bald nicht mehr abstrakt, sondern entstammten dem täglichen Arbeitsleben im Geiste christlicher Hoffnung ...

Lange hat der Verfasser die Rolle des Kommunikators nach dem alten Kommunikationsmodell gesehen. Inzwischen versteht er, daß es viel mehr seine Aufgabe ist, eine Atmosphäre zu schaffen, in der jeder angeregt wird zu eigener Kommunikation. Gruppenmedien können hier zu einer befreienden Kraft in einer Situation unterdrückender Massenmedien werden. Seiner Meinung nach wäre es Zeit für die Kirche, ihre Medien politisch neu zu überdenken: soll man wirklich große Summen in Geräte für Studios und die Bildung einiger weniger Spezialisten ausgeben, die gelegentlich als Teile eines großen "Apparates" arbeiten, um die Kirche auch in Unterdrückungssystemen deutlich zu machen?

Dritte Welt Theologen, besonders in Lateinamerika, haben damit begonnen dic Option der Kirche für die Armen ernst zu nehmen. Wann werden die religiösen Kommunikatoren ihre klimatisierten „Kontroll“-Räume verlassen und zu den Basisgemeinden stoßen, nicht um neue Informationen zu sammeln, sondern um zu kommunizieren?

\section{RESUMÉ}

L'auteur fit, dans une nouvelle paroisse industrielle du Kénia, l'expérience que là-bas l'ancien modèle de communication du message-émetteur et receveur ne fonctionnait pas. Il était confronté à la „culture du silence“. Ce n'est que lorsqu'il essaya, entre autre, le langage-photo et le jeu des rôles qu'il aboutit à une nouvelle formation de la conscience. Alors, seulement, les jeux bibliques et les contes populaires africains qui parlaient de la situation des travailleurs eurent aussi du succès. Une nouvelle conscience de soi crût, renforcée par des communautés chrétiennes de base. La stimulation d'une communication propre se révèla déterminante. En conclusion à cela, l'auteur pose la question suivante: si, dans les régions de répression, l'Eglise ne peut pas renoncer à un gros "appareil“, dans le domaine des mass media. Les communicateurs religieux doivent, selon sa conviction, se porter en avant des communautés de base afin de "communiquer" là-bas. 


\section{RESUMEN}

En una nueva parroquia de una zona industrial de Kenia el autor pudo comprobar que allí fracaso el antiguo modelo de comunicación que coloca al receptor frente al mensaje emitido. Quedó confrontado con la "cultura del silencio“. Recién cuando lo intentó a través del lenguaje fotográfico y de escenificaciones se llegó poco a poco a una nueva formación de la consciencia. Sólo entonces encontraron eco representaciones bíblicas y cuentos africanos relacionados con la situación de los obreros. Un rotativo local se convirtió en foro de los obreros. Nació una nueva consciencia, robustecida por comunidades cristianas de base. La promoción de propia comunicación se mostró como decisiva. El autor se pregunta si en las regiones oprimidas la Iglesia no debería prescindir de gran „aparato“ en el terreno de los medios de comunicación. Los comunicantes religiosos deben, en su opinión, llevar su convencimiento a las comunidades de base para "comulgar" allí. 